\title{
Article \\ Quality Labels as Drivers of Peri-Urban Livestock Systems Resilience
}

\author{
Rosalia Filippini ${ }^{1,2, *}$, Sabine Gennai-Schott ${ }^{3}{ }^{(0)}$, Tiziana Sabbatini ${ }^{3}$, Sylvie Lardon ${ }^{2}$ and \\ Elisa Marraccini ${ }^{4}$ (D) \\ 1 Department of Health, Animal Science and Food Safety, Università degli Studi di Milano, Via Celoria, 10, \\ 20133 Milano, Italy \\ 2 INRAE \& AgroParisTech, UMR Territoires, 63000 Clermont-Ferrand, France; sylvie.lardon@agroparistech.fr \\ 3 Institute of Life Sciences, Sant'Anna School of Advanced Studies of Pisa, Piazza Martiri della Libertà 1, \\ 56127 Pisa, Italy; sabine.gennaischott@gmail.com (S.G.-S.); tiziana.sabbatini@santannapisa.it (T.S.) \\ 4 InTerACT (UP 2018.C102), UniLaSalle, 19, rue Pierre Waguet, 60026 Beauvais, France; \\ Elisa.Marraccini@unilasalle.fr \\ * Correspondence: rosalia.filippini@unimi.it
}

Received: 15 May 2020; Accepted: 22 June 2020; Published: 30 June 2020

\begin{abstract}
Livestock farming systems have an important role in the territorial systems of the Mediterranean, but in the last twenty years the sector has undergone serious changes with an important decrease in the number of farms. The purpose of this study is to show the contribution of a local food certification to the resilience of peri-urban livestock farming system and of its food supply chain at territorial level. The focus is on the "Carne Bovina di Pisa" project, a private label promoted by the local livestock producers' association, with the purpose of preserving biodiversity and provide farmers with an opportunity to strengthen their local marketing power. The case study is the peri-urban area of Pisa (Tuscany, Italy), representative of the urbanized Mediterranean coastal plains with high urban pressure on agricultural land and increasing agricultural abandonment in the peri-urban area. The analysis is based on the qualitative analysis of interviews to stakeholders and the quantitative figures about the changes in livestock system. Results show that the label has positively sustained both the resilience of farming systems and the local food supply chains.
\end{abstract}

Keywords: localized agro-food systems; peri-urban farm; cattle farm; Italy

\section{Introduction}

The term resilience has been recently widely used in farming system literature. The resilience of a socio-ecological system such as a farming system is defined as the capability to absorb disturbances and rearrangements, while maintaining the same function, structure, and identity [1]. According to López-Ridaura et al. (2005) [2], the resilience of the agricultural system is one of the key elements in assessing its sustainability. While the sustainability is defined by the capacity of a system to function in the future, the resilience is the capability of the system to continuously provide a function over time despite disturbance. It is thus seen as a means to achieve sustainability in case of disturbances [3].

Darnhofer (2014) [4] highlights the importance of the term "capability" in the definition and identification of resilience. The use of this term is important to highlight the fact that the resilience is not a mere automatic response activated by the system to react to a shock, but it implies the "ability to identify opportunities, to mobilize resources, to implement options, to develop processes, to learn as a part of an iterative, reflexive process" [4] (p.467).

Scholars have thus identified three types of capabilities that sustain a system's resilience strategy $[5,6]$. The buffer capability is the capacity of the system to persist, by assimilating the 
perturbation without changing its structure or its function. In opposition to rigidity, it refers to the ability of the farm to mobilize resources facing small disturbances, especially in the initial phases of large shocks. The adaptation capability refers to the ability of the system to adjust to disturbances. In this case the changes are marginal, in the way that something is simply added to current structures and functions. Finally, the transformative capability refers to the ability to adopt radical changes $[5,6]$. It is not always possible to decide if the resilience strategy operated by the system is of one kind or another. This is because the changing process is dynamic over time and the three behaviors are not exclusive to one to another. For example, during the evolution, adaptive changes can sum up and become transformative [4].

The actors of the farming system resilience can be detected at farm scale, being the single farmers that directly act, and at the territorial and regional scales, where the attention is focused on the strategies of different actors in addressing the resilience of rural areas [7].

According to literature, in analyzing the resilience strategy of the system it is essential to identify "the resilience of what", "the resilience to what", and "the resilience for what purposes" [8,9]. In the first case, it is important to identify the system that is the object of the analysis, also specifying its boundaries. In the second case, it is essential to identify the economic, environmental, social, and institutional challenges that could impede the ability of the system to deliver the desired public and private goods. Finally, in the third case it is essential to highlight what is the desired final result of the resilience strategy.

This study is focused on the resilience of the livestock systems in peri-urban areas. Here, we define the peri-urban farming system as the farming system that is located close to the urban area. Especially the study is interested in the beef cattle production performed around urban areas.

Livestock systems in peri-urban areas have been particularly affected by global and local disturbances. Global challenges depend on the global market dynamics, the socio-political and environmental development, such as the economic crisis and raw material price volatility, or the climate change. In this framework, the abolition of the quota system in 2015 was subsequent to a rise in the milk production in the European Union and a consequent decrease of the prices and profits for the farmers [10]. The emergence of periodic global food safety crises such as Avian influenza or Bovine Spongiform Encephalopathy (BSE), had strong consequences locally on the farming systems, especially on the cattle production, at the same time as alarming the public. As assessed by the OECD [11], in Europe, the meat consumption severely plunged in the early 2000s, and since 2013 it seemed to rise but at a slow and inconstant pace. At the same time in the European Union, the prices for cattle production record a decreasing tendency from 2010 to 2019 [12].

One of the challenges that the livestock sector had to face in the last decades was a common intensification trend in the European Union including the European Mediterranean Basin, characterized by a high decrease of the farm numbers and a stable amount or increase of the livestock units per farm [8]. The evolution of the livestock farming system has led to a progressive livestock specialization against a crop-livestock integration. This was due to the economic concentration and the economy of scale, which led farmers to focus on highly productive breeds, confinement systems, and off-farm feed purchase [13]. At the same time, farms tended to abandon livestock and specialize in crops because of the higher cost of manpower in livestock productions and the complexity of the workload, which is connected to the changing regulations for livestock stables and animal welfare [14]. According to the literature $[13,14]$, the disappearance of the local food supply chains, due to the disappearance of key-actors such as small slaughterhouses, has also led to a stronger connection to the uncertain global dynamics and thus to a lower economic valorization and profitability for livestock farms. This has eventually led to the abandonment of the livestock production in favor of crop production [14].

Among the local challenges, the urban pressure and the urban sprawl which characterize the Mediterranean European area is a serious stake for the development of farming system, since it has often led to a decrease in agricultural surface, due to competition for land use between agriculture and the urban area [15]. 
In the European Mediterranean context, livestock production in peri-urban areas is particularly at stake due to the constraints it has to face, such as the rules related to manure spreading, the lack of manpower, the production of nuisance, as well as the social conflicts with new urban residents and so forth.

Global and local dynamics may thus play together posing serious questions for the resilience of the peri-urban livestock system. In this framework, scholars have claimed that the proximity to urban areas and its consumers may be a source of resilience, because it enables more direct contact with local consumers [16,17]. However, the progressive decrease in the number of livestock farms may lead to a crisis in the overall value chain. Nowadays consumers are more prone to buy local food, but without the farmers producing locally, the economic actors participating in the value chain-small butcheries, slaughterhouses, groceries-may also be in crisis, with consequences in the resilience of the local food system [18]. At the same time, the contribution of the traditional conventional value chain's actors in the local chain for the development of a reliable local food supply chain is underestimated [19]. Bloom and Hinrichs (2011) [19], for example, denounce the frustration of urban buyers and distributors in making direct commercial agreements with farmers when they participate in local food chains, even though the participation of these actors can be a driver for scaling up the local food system and thus positively influencing the local food economy, which in the end is the purpose of the local food system movement.

Livestock dynamics in urban areas have been addressed by several scholars [20-23]; however, these case studies mostly focus on developing countries (see the recent review of Hatab et al., 2019 [24]) and very few of them concern Mediterranean areas [25-28]. Up to now, the interest of literature on the peri-urban livestock farming system in developed countries has been focused especially in analyzing its social functions, as in social and leisure farming, and less for its production capacity [23,29-31].

Thus, in this study the resilience strategy aims to enable the peri-urban livestock production to produce food and thus contribute to the feeding of the local population. Especially, the presence of a livestock production integrated with the cropping system is also essential for the maintenance of the soil fertility [32] in peri-urban areas. The benefits of livestock production integrated with cropping systems, both at farm and territorial levels, may positively affect the resilience of the livestock farming system and the sustainable development of the agricultural area $[8,21]$. First, farms have the possibility to reduce external inputs, such as feed, fertilizers, and pesticides, via an efficient recycling of crops and livestock products, such as manure, straw, and others. This strategy also reduces the environmental externalities and allows farms to produce efficiently [32]. Second, at territorial level, the livestock-crop integration creates opportunities for synergistic resources transfers between farms. For instance, the manure exchange improves the soil structure and fertility at a territorial level, the crops exchange allows more efficiency in the diets; thus, reducing environmental impacts [33]. For all these reasons, the resilience of livestock production in peri-urban areas should be analyzed more in detail for its productive role. Moreover, the presence of livestock farms close to the consumers, and the possibility of on-farm direct sales, reassures the consumers of the production's quality, as well as making them participants to the environmental sustainability [34]. According to studies [16,22,23], there is a correspondence between the presence of local meat labels and the maintaining of livestock production in peri-urban areas. This is consistent with the literature on resilience strategies of farmers [7]. Among the resilience strategies operated by farmers, Ashkenazy et al. (2018) [7] detected the valuing of local artisanal capacity by farmers. In opposition to the standardization and modernization of farming practices and products, with this resilience strategy farmers base their profit on the niche markets created for products that are unique and symbolize specific characters of the social and natural environment of a specific place. To do so, the farmers need to coordinate themselves with the local and regional stakeholders.

The hypothesis of this study is that the resilience of the peri-urban livestock farming system may contribute to the resilience of the local food system through the use of a local label and vice versa, with benefits not on only for farmers but also for the different economic actors of the supply chain. 
The aim of this study is to show the contribution of a local food certification in the resilience of a peri-urban livestock farming system (beef cattle) and of its food supply chain at territorial level. The label analyzed is the Carne Bovina di Pisa, a private food quality label, specifically designed to maintain the livestock production in areas where livestock farms are decreasing.

This study does not simply focus on how artisanal and typical production can be drivers for the resilience [7], but on the specific case of a quality label. The reason is that the food quality label usually groups not only farmers and public stakeholders, but also commercial actors, such as distributors, supermarkets, butcheries, and slaughterhouses. When participating in a product specification all these actors need to adhere to rules and coordinate themselves to ensure the economic reliability of the system. This is especially sustained by the literature that studies the Localized Agro-Food System (LAFS) [35,36].

In the next paragraphs, first we introduce the LAFS as the approach of analysis used. Then, we explain the origin and the recent evolution of the agro-food project Carne Bovina di Pisa (CBP) to set the starting point of the analysis. Subsequently we describe the data used to assess the current situation of the project and finally we propose the results and their discussion in light of the literature about the farming system resilience and the LAFS.

\section{The Localised Agro-Food Systems}

The LAFS, also known as SYAL (localized agro-food systems/Systèmes Agro-alimentaires Localisés), "intends to enhance the local resources and to understand the territorial embeddedness of agricultural and agro-food productions, considering the local territorial specificities of products derived from them, the local socio-economical organizations, involved in the production process, the methods of valorization of products, the consumers' representations and the symbolic value of products" [37]. In the LAFS, the development of local places relies on the identification and activation of local resources connected to the agricultural activity and the cultural values attached to the agro-food product. [37]. To ensure such activation, it is necessary that stakeholders are all organized together and adhere to a specific system of values, which is symbolized by a specialty food product, which encompasses both natural and immaterial resources and to which the "quality" is assigned [38]. In other words, beyond the geographical proximity of actors, what defines a LAFS is the presence of an organizational proximity [39].

A LAFS is thus characterized by two main elements: (i) A concentration of farms, firms and institutions that are geographically and/or organizationally proximal. In other words, they can be located in the same geographic area, and/or they are organized together by the sharing of the same cultural values. (ii) Its development is based on the production of a specific quality agro-food product, whose quality is characterized by a certain degree of origin specification, traditional savoir-faire, cultural values, and territorial anchorage.

According to literature, the LAFS are both the object of research and an approach to analyze the development of local resources [40]. In the analysis of local food systems, the LAFS research can be focused on different topics: how the actors coordinate themselves, their social networks, their collective actions, and the governance of the value chain; how the product is qualified through the definition of regulations, specifications, development frameworks; the material and immaterial resources' management, such as the natural resources and the know-how, which is both traditional and innovative; and the dynamics and flux of knowledge and competences [27]. Especially in the framework of a local food system's analysis it allows the enhancement of the links between the different economic actors of the value chain such as farmers, processors, distributors, and to also consider the different territorial scales in which the actors are operating in order to study in deep the territorial anchorage of these activities, and thus understand the possible link between rural and urban activities [27].

Nevertheless, up to now and to the best of our knowledge, no studies have been developed in the framework of LAFS literature on the peri-urban farming system and on its inclusion in quality scheme. 
This is relevant considering the specific territorial conditions of production of peri-urban areas [41,42], which may affect the territorial anchorage of the food chains. At the same time, scholars have moved critics on the effective capacity to valorize the heterogeneity of the farming system operating in those places, considering also the specific territorial conditions of production that may ask farmers to adapt the production process. The expression "commodification of place and regions through food" has been used to refer to the process that LAFS scholar risk to operate, by which a product is fixed to a place [43]. In this process, the risk is to simplify the image of the place of production, by defining a place as "local", considers only the values and meanings connected to one specific quality product [44] more than the natural and territorial dynamics, without taking into account the specific characters of the different places of production under the umbrella of the same product qualification. This study thus wants to provide new insights about the possible integration of farming systems with different spatial conditions of production in the same quality scheme, to better valorize the territorial anchorage of value chains and food network.

\section{Case Study}

The peri-urban area of Pisa (Figure 1) is composed by a group of seven municipalities around the main town of Pisa in the northern-west Tuscany (Italy). As several Mediterranean peri-urban areas, this area is undergoing a process of urbanization [45] and in the meantime of relocalization of agricultural activities [46]. Livestock breeding is one of the main traditional farming activities in the area in small-scale mixed farms since the land reclamation and land reform in the second part of the 20th century. However, traditional mixed arable and livestock farms are becoming arable farms and the number of cattle and sheep farms have decreased significantly during the 1980-2010 time span (84\% for cattle farms and $73 \%$ for sheep farms) according to the agricultural census.

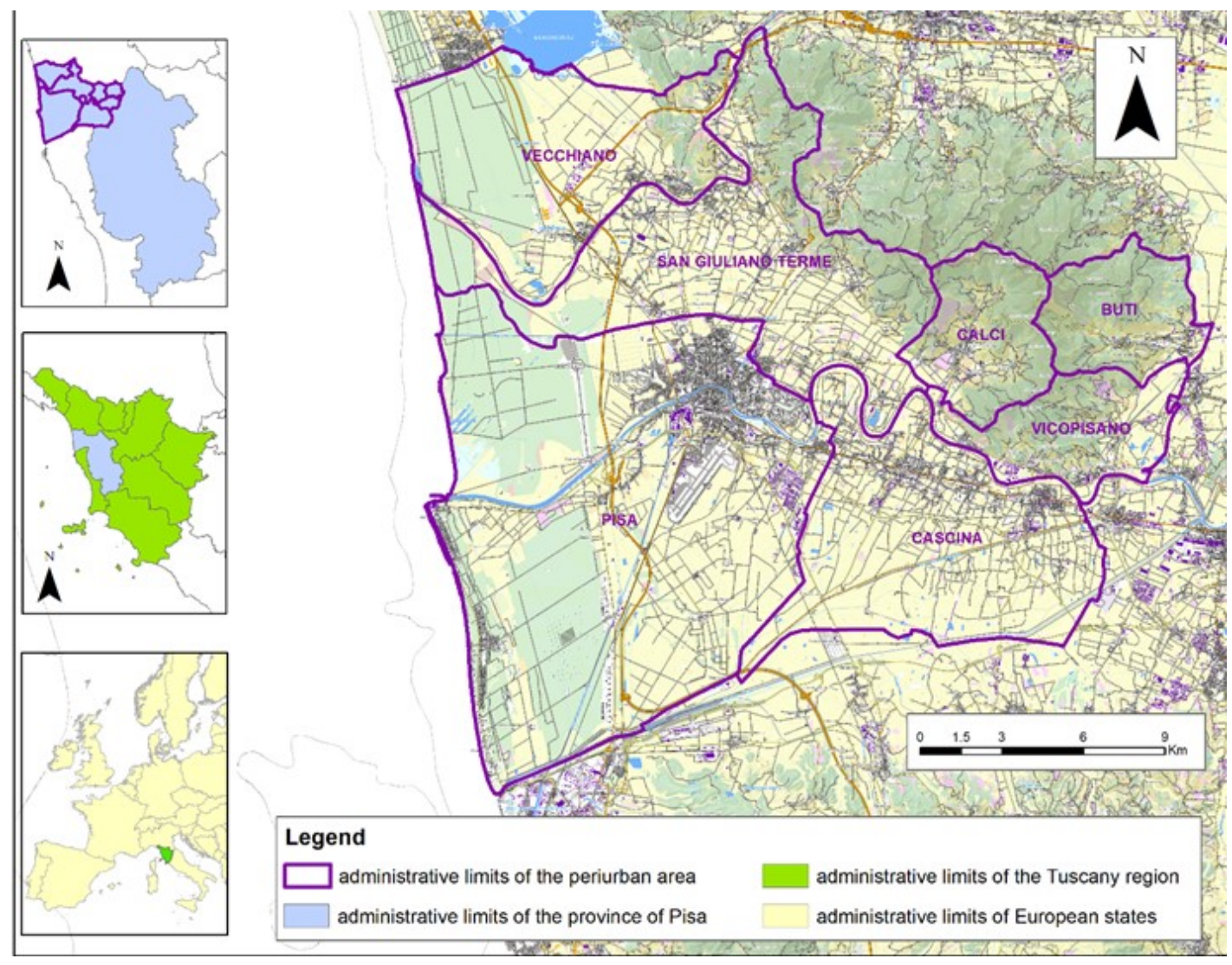

Figure 1. The case study in the peri-urban area of Pisa (Italy). 


\section{The Carne Bovina di Pisa Project}

In 2013 the authors focused on the Carne Bovina di Pisa (CBP) project by surveying the actors involved: three farmers (out of the seven farms contributing to the label), one butchery, one slaughterhouse, two supermarkets, the livestock producers' association (APA), and the Tuscan region. This paragraph explains the origin of the project according to the 2013 surveys analysis and the change in the label that occurred in 2017, in order to set the starting point of this manuscripts' analysis.

The CBP project was initiated by the APA in 2000 by the definition of the product specification. The purpose of the project was to preserve the gene pool of local cattle, the Mucca Pisana, by organizing a local food supply chain to valorize such local breed. The Mucca Pisana is a mixed race, native to the Province of Pisa, recognized as one of the 16 minor Italian cattle breeds of limited diffusion and protected by the Italian ministry of agriculture [47]. Traditionally used in the area as a triple purpose race (milk, meat, and labor), it started to decrease with the agricultural mechanization and the specialization of dairy production. Recognized as an endangered breed, in the early 1990s there were just 250 animals in the Province of Pisa, mainly hosted in small farms, which sell the meat with a too low price to assure a properly economic development. Several efforts were thus pursued to protect the existing animals. Moreover, in the early 2000 the BSE began to seriously spread in Europe and in Italy, and the idea of labelling local meat was a tool to assure consumers about the traceability and the quality of the food production. As a result, the CPB project started in 2000 to highlight the typicality and localness of the meat certified by the project, in coherence with the cultural and social identity of the consumers (Figure 2a). The commercialization of the meat was in fact especially addressed for a local consumption. Beyond the Mucca Pisana, the label also covered the production of the Limousine breed in the Pisa province. The Limousine is originally from the region of Limousine in France and it is now one of the most widespread beef cattle breeds in Europe. By associating these two breeds in the same label, APA guaranteed to the farmers the possibility to differentiate their production, and thus their offer on the market. On one side, the Mucca Pisana is a local recognized production, but one that needs specific artisanal competencies for its production and for the processing of its meat; the Limousine even though it is not a local original breed, is well spread in the area and can profit from a more standardized processing of the meat.

a)

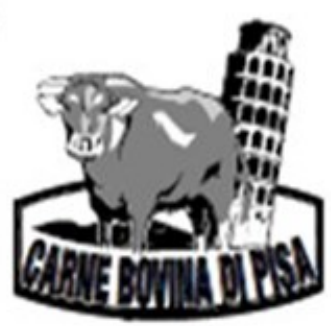

b)

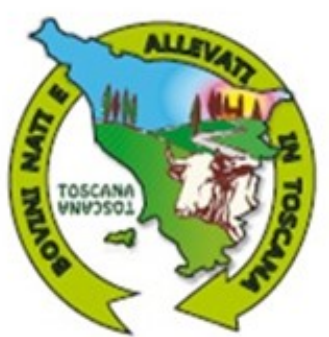

Figure 2. (a) The label Carne Bovina di Pisa; (b) the label Toscana Toscana. Source: website of Toscana Toscana label.

Through the CBP project, it was thus possible to coordinate the different stakeholders, i.e., farmers, local livestock producers' association, slaughterhouses, and local supermarkets, around a common label, which distinguished the livestock produced in the Province of Pisa. In the area, there is also the Vitellone Bianco dell'Appennino toscano Protected Geographical Indication (GPI), protecting the Chianina beef cattle breed, the dominant local breed in Tuscany. As a result, there was a lack of quality labels for other kinds of breeds.

The success of the CBP project was evident in the first surveys of 2013: the Mucca Pisana tripled in few years, from 200 to 600 units. At the same, on the marketing side, the project was able to include other actors, two big supermarkets, several restaurants, and some shops. It was also evident that the project helped farmers to diversify their marketing strategy, further contributing to their 
development [48]. A special character of the project that was observed in 2013, related to the fact that the farms participating in the project were mostly located in the peri-urban area of Pisa.

In 2017 the regional livestock association created the unique regional label "Toscana Toscana" for beef cattle production, for animals born and raised in Tuscany (Figure $2 b$ ). This choice enabled the inclusion of other actors beyond the borders of the Province of Pisa; more farmers, more slaughterhouses and butcheries, and more supermarkets, shops, restaurants, and so on. Nevertheless, in the Province of Pisa, the reference to CBP is still applied on the label, since it is well recognized by the consumers in Pisa's supermarkets [49].

The new label is recognized by the Region of Tuscany and guaranteed by APA, and it is on the way to be accredited in the national registry of voluntary traceability. The product specification limits the breed, the origin, and the feeding. For the origin, the animal should be born in Tuscany but grown in the Province of Pisa. For feeding, the feed must come primarily from the farms where the animals are grown, and the rest must come from the certified national supply chain without GMO, and that animals cannot be feed with silage in the three months before the slaughtering [50].

\section{Material and Methods}

We performed the analysis in two main steps: a statistical analysis of beef cattle farms in the peri-urban area of Pisa in order to observe the general dynamics of livestock in the area and thus their capacity to respond to global and local shocks and a qualitative analysis of the interviews to stakeholders involved in the Carne Bovina di Pisa project in order to understand the adaptation capacity of the different stakeholders of CBP.

\subsection{Quantitative Analysis}

In a first step, we accounted for the livestock farms and livestock unit dynamics in the peri-urban area of Pisa (Italy), according to the annual livestock census data [51]. We focused on the number of beef cattle farms, on the beef cattle livestock units (LSU), and the beef cattle LSU per breeds in the area, particularly those of interest for the Carne Bovina di Pisa project (Mucca Pisana and Limousine) compared to the other common breeds in the area or to other protected breeds (e.g., Chianina). If, for the number of livestock cattle farms and cattle LSU, a long-term analysis had been possible, the detail of the LSU belonging to different breeds were available only in the short term (2017-2019).

\subsection{Qualitative Analysis}

\subsubsection{Interviews}

In 2018, interviews were conducted to relevant stakeholders involved in the CBP label to assess the recent evolution of the project since 2013. Table 1 shows the actors interviewed as well as their main role in the label. The open questionnaires were composed of several parts, aiming to understand the role of each actor in CBP, the reason that led the actor to participate, the expectations for the future. The two farmers interviewed are both located in the peri-urban area of Pisa. They were selected because they participated in the 2013 survey and because they have two different strategies of production and marketing strategies. FAR3 is a private farm, which breeds both Mucca Pisana and Limousine and sells both in supermarkets and through on-farm direct sale. FAR15 is a public farm, but with private management. The farm only breeds Mucca Pisana, which only sells to supermarkets.

The supermarket SUP1 is a big Italian supermarket company. In our case, stores of this supermarket chain are located both in the peri-urban area of Pisa, and in rural areas of the Province of Pisa. The different shops have different capacities for processing and selling the meat depending on their location and dimension. We interviewed the regional marketing director, and thus able to represent both the company purposes connected to the label and the different strategies of the single stores. All stores of SUP1 are managed by the owners who independently manage the sales point, a fact that is not common to the rest of the large-scale retail trade. They know the territory and receive direct 
feedback from it, they have knowledge of local products, so the link with the territory is much stronger and potentially they can better respond to consumer demands than SUP3. On the contrary, SUP3 is part of a big international supermarket company. Despite its international character, the supermarket has developed a strong strategy in supporting local production and local agriculture. Moreover, in our case study, there was only one big store of the SUP3 chain commercialising CBP meat located in the city of Pisa, which thus represented the urban perspective.

APA is the local representativeness of the regional association of livestock producers. Its main function is to represent livestock producers' interests, technical assistance, and the improvement and the preserving of the gene pool of cattle breed. They are responsible for the management of several origin certifications beyond CBP, i.e., "PGI Chianina" and "Agnello da latte pisano".

Table 1. Actors description. FARn indicates the surveyed farms; SUPn, the supermarkets; and APA, the local livestock association.

\begin{tabular}{cccc}
\hline Actors $\left(\mathbf{n}^{\circ}\right)$ & Description & Main Role in the Project & Code \\
\hline Farmers (2) & Private actor (1) and & Production (2) and direct sale (1) & FAR1; FAR2; \\
Puplic actor (1: University) & Private actor & Processing (1) and sale (2) & SUP2; SUP3 \\
$\begin{array}{c}\text { Regional livestock } \\
\text { association (1) }\end{array}$ & Private-public actor & Initiative and coordination & APA \\
\hline
\end{tabular}

\subsubsection{Qualitative Data Analysis}

The qualitative data from the interviews were analyzed considering two frameworks. First, the data were used to highlight the food supply chain of the CBP. In the supply chain, the relationships among the actors are defined by considering the reciprocal power between them. The aim is to study the vertical concatenation of the different actions' actors perform, from production to consumption, that add value to the final product sold to the consumers. The supply chain was thus built up considering the functions that add value to the production process and the actors responsible for each specific function.

Second, the data were analyzed through the perspective of the network approach. In a food network analysis, the focus is on the horizontal relationships, where the concatenations of actions are contextualized in the "social life" of food [52]. Since in the agro-food system, a multiple set of social, economic, and political elements may play a determinant role, the network analysis enables the understanding on how actors perform the relationships, taking them without considering any already existing marketing power [53]. According to authors, this attention should be especially paid on how local actors are able to maintain local agro-food networks [53]. The network will be designed in the way that each actor is a node of the network and the links define the relationships among the actors.

\section{Results}

\subsection{Cattle Farms Dynamics in the Area}

To understand the medium-term dynamics of cattle farms in the Area Pisana, Figure 3 shows the data of the annual livestock census at the municipal level. From 2004 to 2015, the overall number of cattle farms showed a general tendency at the Area Pisana level to decrease in the area. In 2019, after a few years of stability, the number of cattle farms vastly increased for the first time since 2004. This trend was similar in three out of four municipalities having the larger number of beef cattle farms.

When looking at the beef cattle LSU in the municipalities having the highest number of beef cattle farms (Figure 4), we can observe an increase of the beef cattle LSU from 2002 to 2003 and a general decrease from 2003 to 2018, then an increase from 2018 to 2019 consistent with the increase in the beef cattle farms highlighted in Figure 3. This suggests that the increase of LSU was not due to an intensification of the already existing beef cattle farms. We can also notice that the LSU was more stable in some municipalities, e.g., Cascina, and more variable in others, e.g., Vecchiano. 


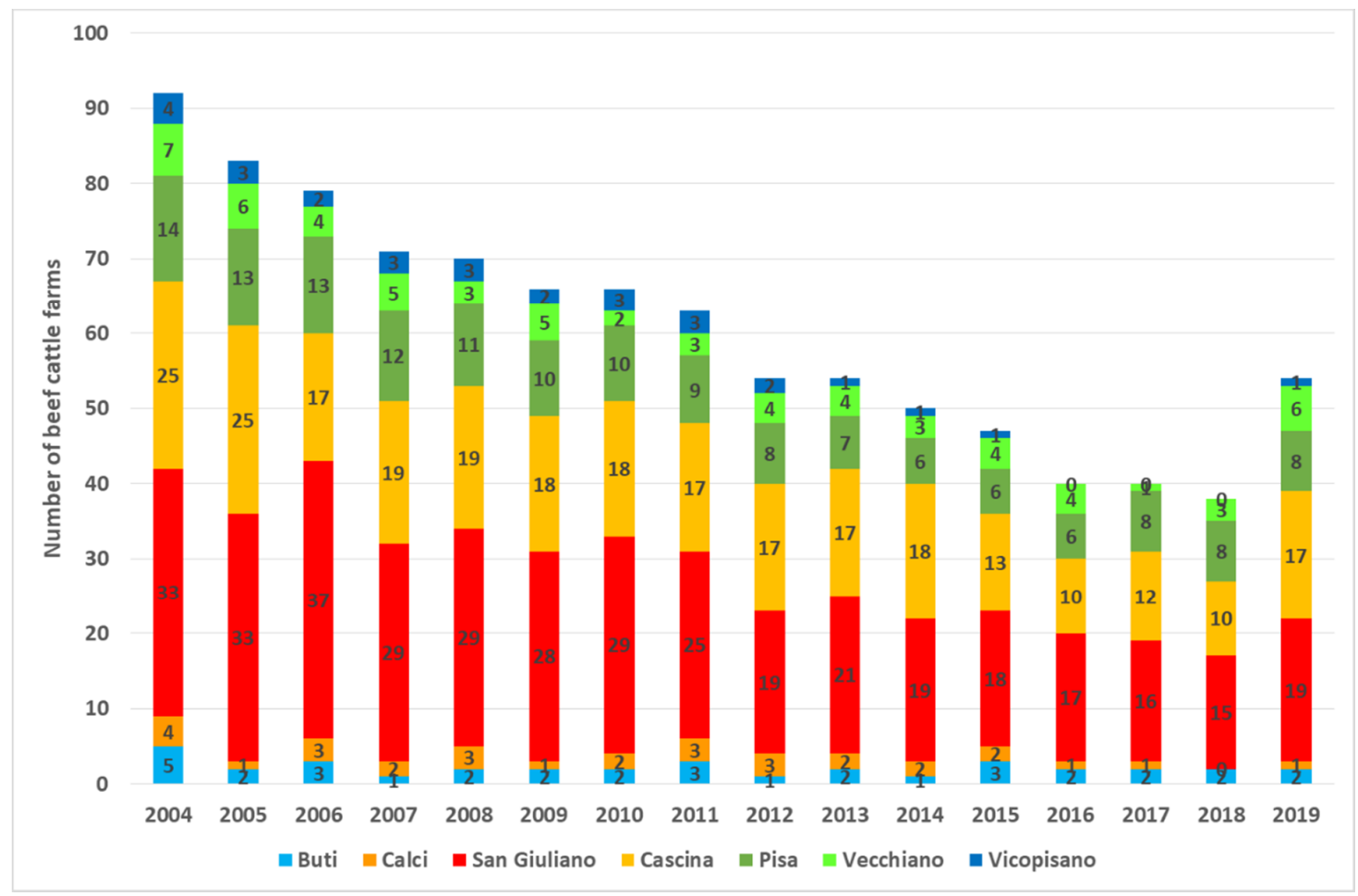

Figure 3. Short term dynamics of cattle farms in the Area Pisana municipalities (Italy). Source of the data: Istituto Zooprofilattico Sperimentale, 2020.

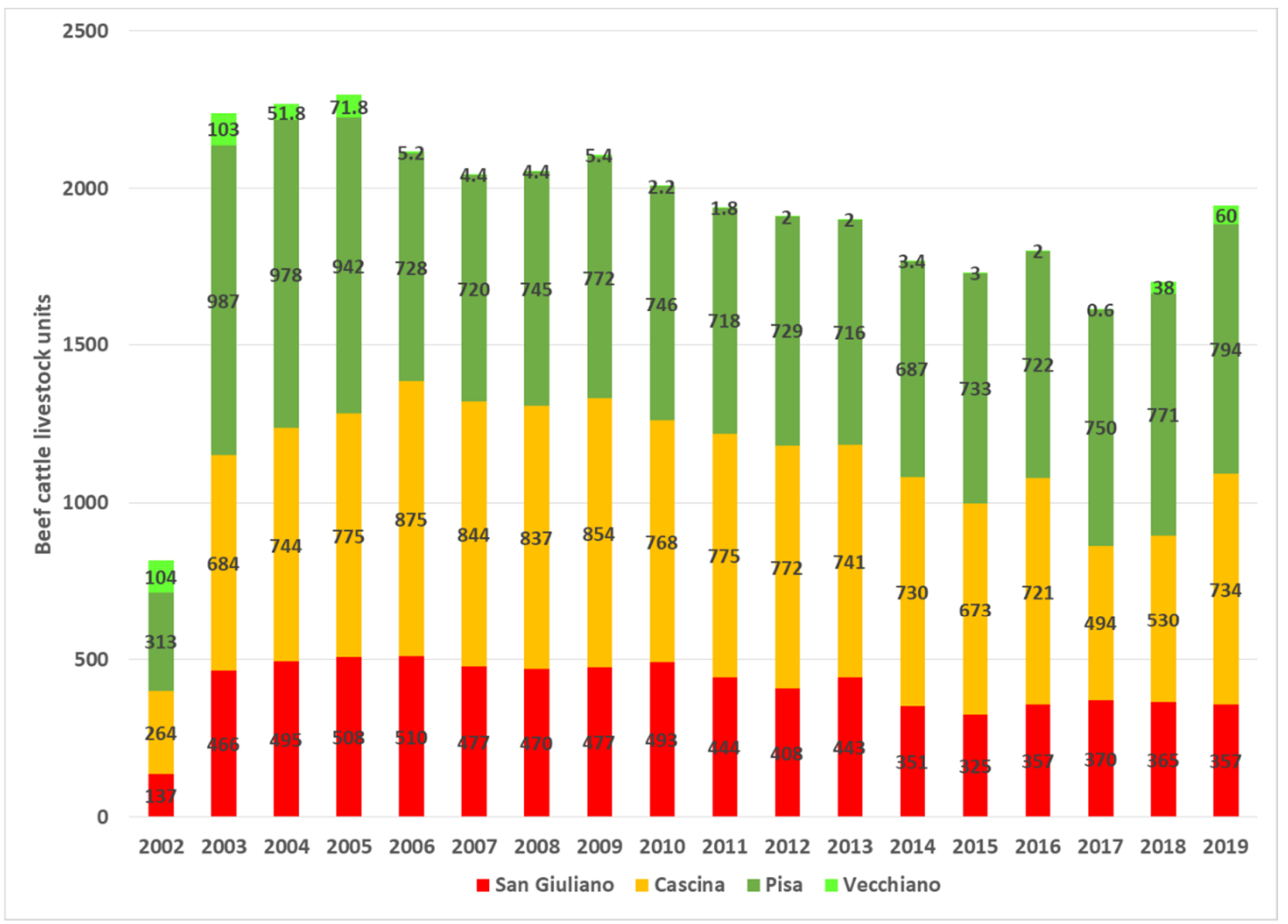

Figure 4. Short-term dynamics of beef cattle livestock units in the four most livestock-oriented municipalities of peri-urban area of Pisa (Italy). Source of the data: Istituto Zooprofilattico Sperimentale, 2020. 
When looking at the main beef cattle breed, it is possible to observe three different short-term dynamics in the 2017-2019 time span (data not shown). In the first one, the beef cattle LSU per breed was stable, as it is the case of the local Mucca Pisana (2.5\% of the total cattle units), as well as the Limousine, which was common breed (19\%). In the second one, beef cattle units per breed decreased, such as for the Chianina, another local breed protected through a PGI (from $18.5 \%$ to $12 \%$ of the total cattle units) or the Charolais, a common breed (from $8.4 \%$ to $0.8 \%$ of the total cattle units). Finally, in the third one, the number of beef cattle units increased, and it was only the case of crossbreed cattle (from $44 \%$ to $57 \%$ of the cattle units). However, for crossbreeds, the origin of cattle was unknown, as they are often a mix of common and local breed.

\subsection{Livestock Farms in the Carne Bovina di Pisa Label}

In 2019, 22 livestock farms participated in the CBP label. The main characteristics of these farms in terms of livestock production and the cattle commercialization are illustrated in Table 2. Since 2013, the farms not only increased, but they differentiated themselves both in their production and in their marketing strategies.

Table 2. Characteristics of farmers participating in the Carne Bovina di Pisa label in 2018 (Source: own survey to APA). PU refers to peri-urban area, RU refers to rural areas, CC refers to complete cycle, FAT refers to the farms that only do the fattening, BORN refers to the farms that only give birth to the animals, LI refers to the Limousine breed, MP refers to the Mucca Pisana breed, LSU refers to the livestock unit; SFSC refers to the sale in short food supply chains; and n/a., not available. In bold, the farms surveyed in 2013 and 2018.

\begin{tabular}{|c|c|c|c|c|c|c|c|c|}
\hline & Localization & Production & Breed & LSU & $\begin{array}{l}\% \text { in } \\
\text { SFSC }\end{array}$ & $\begin{array}{c}\% \text { to the } \\
\text { Supermarket }\end{array}$ & $\begin{array}{c}\% \text { to } \\
\text { Butchery }\end{array}$ & $\begin{array}{c}\% \text { to } \\
\text { Farmers }\end{array}$ \\
\hline FAR1 & PU & $\mathrm{CC}$ & MP & 50 & 70 & 30 & 0 & 0 \\
\hline FAR2 & PU & $\mathrm{CC}$ & MP & 50 & 0 & 100 & 0 & 0 \\
\hline FAR3 & PU & $\mathrm{CC}$ & LI & 20 & 0 & 100 & 0 & 0 \\
\hline FAR4 & PU & $\mathrm{CC}$ & LI & 60 & 0 & 25 & n/a. & n/a. \\
\hline FAR5 & PU & $\mathrm{CC}$ & MP & 30 & 0 & 100 & 0 & 0 \\
\hline FAR6 & PU & $\mathrm{CC}$ & LI & 30 & 0 & 100 & 0 & 0 \\
\hline FAR7 & PU & $\mathrm{CC}$ & LI & 20 & 80 & 20 & 0 & 0 \\
\hline FAR8 & PU & BORN & LI & 50 & 0 & 0 & 0 & 100 \\
\hline FAR9 & PU & BORN & $\mathrm{MP}$ & 30 & 0 & 0 & 0 & 100 \\
\hline FAR10 & PU & BORN & LI & 40 & 0 & 5 & 0 & 95 \\
\hline FAR11 & PU & BORN & LI & 40 & 0 & 5 & 0 & 95 \\
\hline FAR12 & PU & $\mathrm{CC}$ & LI & 15 & 0 & 100 & 0 & 0 \\
\hline FAR13 & RU & $\mathrm{CC}$ & LI & 40 & 0 & 100 & 0 & 0 \\
\hline FAR14 & RU & $\mathrm{CC}$ & LI & 20 & 100 & 0 & 0 & 0 \\
\hline FAR15 & RU & FAT & LI & 180 & 0 & 70 & 30 & 0 \\
\hline FAR16 & RU & $\mathrm{CC}$ & LI & 30 & 80 & 20 & 0 & 0 \\
\hline FAR17 & RU & FAT & LI & 20 & 0 & 90 & 10 & 0 \\
\hline FAR18 & RU & $\mathrm{CC}$ & $\mathrm{LI}$ & 7 & 100 & 0 & 0 & 0 \\
\hline FAR19 & RU & FAT & LI & 200 & 0 & 100 & 0 & 0 \\
\hline FAR20 & RU & FAT & LI & 10 & 0 & 0 & 100 & 0 \\
\hline FAR21 & RU & $\mathrm{CC}$ & LI & 6 & 0 & 100 & 0 & 0 \\
\hline FAR22 & RU & $\mathrm{CC}$ & $\mathrm{MP}$ & 100 & 0 & 100 & 0 & 0 \\
\hline
\end{tabular}

In 2013, the label included only seven farms, five of which were located in the peri-urban area of Pisa, and only two in the rural area in the south of the province. The production was thus typical of the peri-urban area. Nowadays the number of farms has grown: twelve farms are located in the peri-urban area, and ten located in the rural area of the Province of Pisa. Thus, the production cannot be considered anymore as specific to the peri-urban area of Pisa. Nevertheless, a different process of production characterizes the farms in peri-urban and non-peri-urban areas. Most of the farms, both in rural and urban areas, are operating a closed cycle. Nevertheless, among the ten peri-urban farms, four do not operate a closed production cycle, but are specialized only in giving birth to the calves that are to be sold. According to the interviews, peri-urban farms often do not have enough space to 
carry out the fattening of the animals. This is the case of farms that are localized close to the urban center, while the other peri-urban farms that are operating a closed production cycle are present in less urbanized areas. Conversely, three of the twelve rural farms specialize in the fattening of the animal. These farms have generally the highest number of animals among all the farms (FAR1 and FAR15), while the farms that operate a closed production cycle do not differ significantly in the farm size. The differentiation between rural and peri-urban farms is significant considering the breed included on the farms. Almost all the Mucca Pisana are in fact bred in peri-urban farms, with the exception of one farm (FAR22). Considering the marketing strategy of the farms, data do not show a differentiation in the commercialization strategy between rural and peri-urban farmers in participating in short food supply chains. In general, the sale to the supermarket is preferred to the sale in short food supply chains and the sale to butcheries. Finally, the peri-urban farmers that do not have a closed production cycle sell to other farms that are participating in the label. Only seven farms participate in different marketing strategies; thus, the hybridization of commercialization is not common in our case study. In general, farms tend to combine the sale to supermarkets with other marketing strategies.

\subsection{Food Chain and Networks of Carne Bovina di Pisa in 2018}

In this section, the networks represent the different kinds of relationships that link the stakeholders, while the food supply chain represents the value chain creation of CBP. APA has actually a central role in all the types of networks, but being a no-profit association, it does not participate in the food value chain.

\subsubsection{Production}

Figure 5 shows the funding network that connects the farmers (FAR), the region (REG), and APA. The project is financed by the European Agricultural Fund for Rural Development connected to protection of biodiversity (here, species biodiversity). The farms receive the funding from the Tuscan region, but the application for funding is still forwarded by APA, according to their role of livestock producers' interests' representatives. The funding is targeted not on the project itself, but only on the breeding of Mucca Pisana. The Rural Development Program that covers such financial support is in fact connected to the biodiversity protection and not to the programs on the value chain support. All actors recognize that the importance of such funding is seriously decreasing. While at the beginning of the project, the role of local and regional institutions, by providing funding and through public promotion, has been significant in initiating the project, nowadays, this role is becoming marginal.

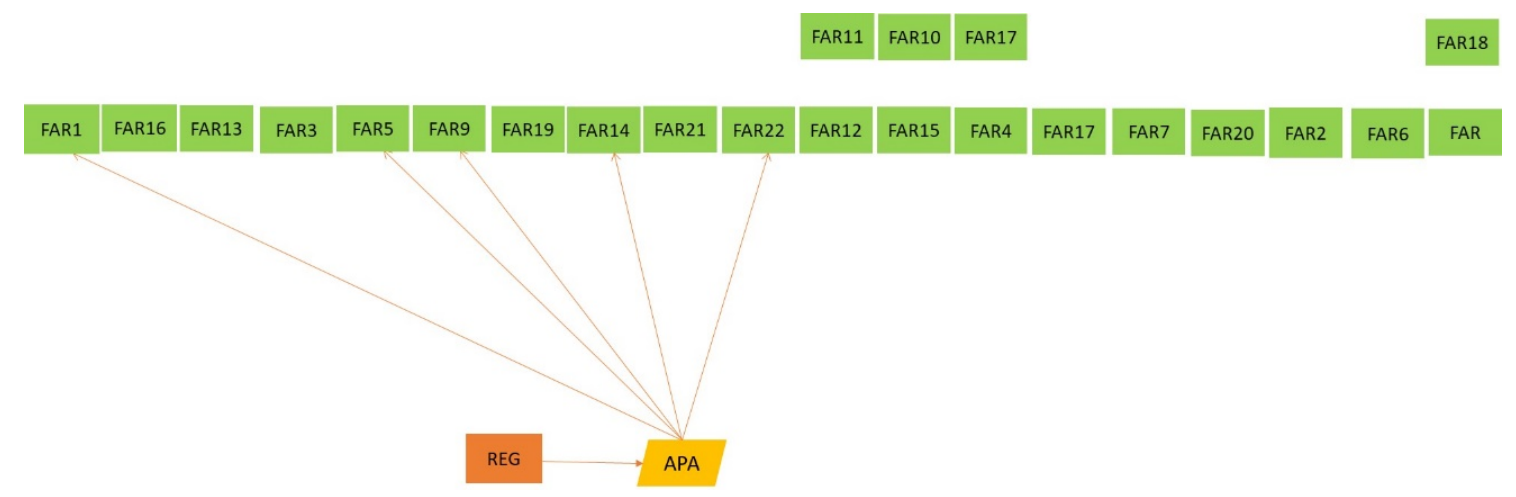

Figure 5. Food network detected in 2018: the funding flow between the region (REG), livestock association (APA), and the farms (FARn). Source: own data.

APA has a central role in monitoring the farms' production. Their mission is to provide technical assistance on the animal breeding for the associated farmers (Figure 6). They monitor how the farmers work, the animal welfare, the constraints farmers may face in developing the production. In this way, the technicians of APA know very well the conditions of the farms and their future development. 
According to APA, farmers do not notice specific constraints in applying the CBP product specification. “They don't even notice it because they are all small farms with traditional breeding systems. Since they are not intensive farms, they do not use particular substances. Their animals are raised mainly with hay; no one does silage because they do not have the possibility. However, they feed with cereal flours that they produce on the farm: barley, corn ... for these reasons unconsciously they find themselves within a production system that is as natural as possible."

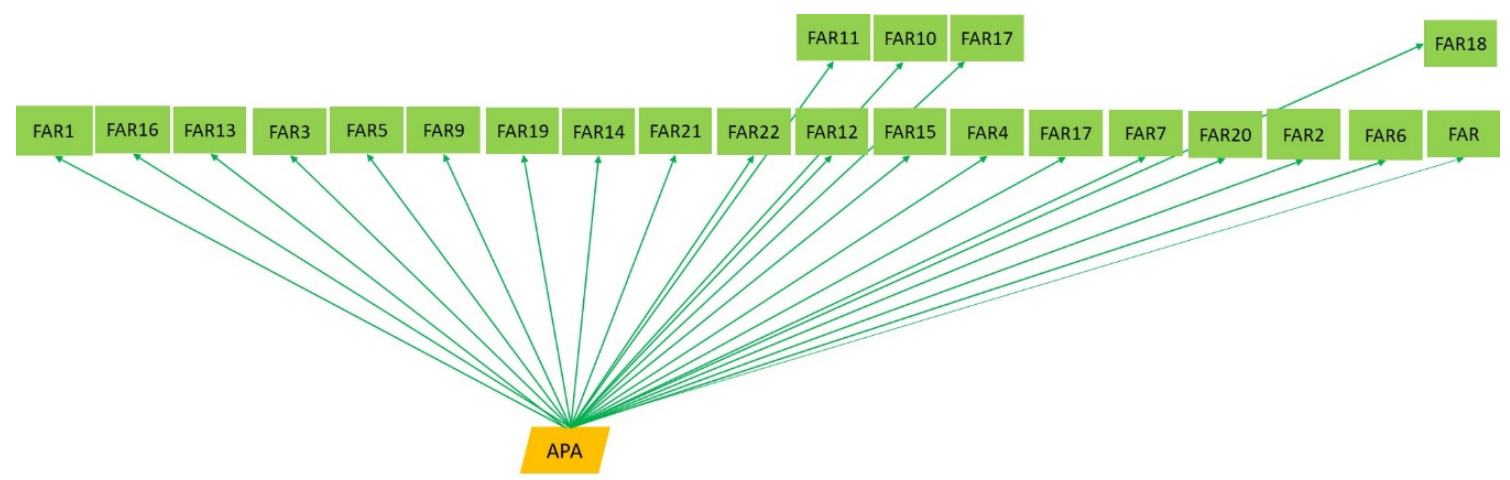

Figure 6. Food network detected in 2018: the technical assistance of the livestock association (APA) to the farms (FARn). Source: own data.

The interviews with the farms confirmed that farmers do not see any constraints in following the label's production specification. Nevertheless, APA noticed a constraint connected to the non-uniformity of the quality produced by the single livestock farms. They are trying to integrate the specification with stricter regulations to uniform the quality, so as to obtain from consumer's side the recognition of a good quality product.

\subsubsection{Commercialization}

To properly study the commercialization, the analysis is divided in 2 parts: the value chain and the food network.

Table 2 shows that the production phase is divided into two main farming practices (Figure 7). There are farms that have a closed production cycle (FARMcc) and farms (FARMborn) that do only the breeding of the animal and sell the young animals to farms that do only the fattening of the animals (FARMfat). Consequently, the food chain contains two different steps in the production that imply a prolongation of the food chain and a further distance between the production and the consumption phase.

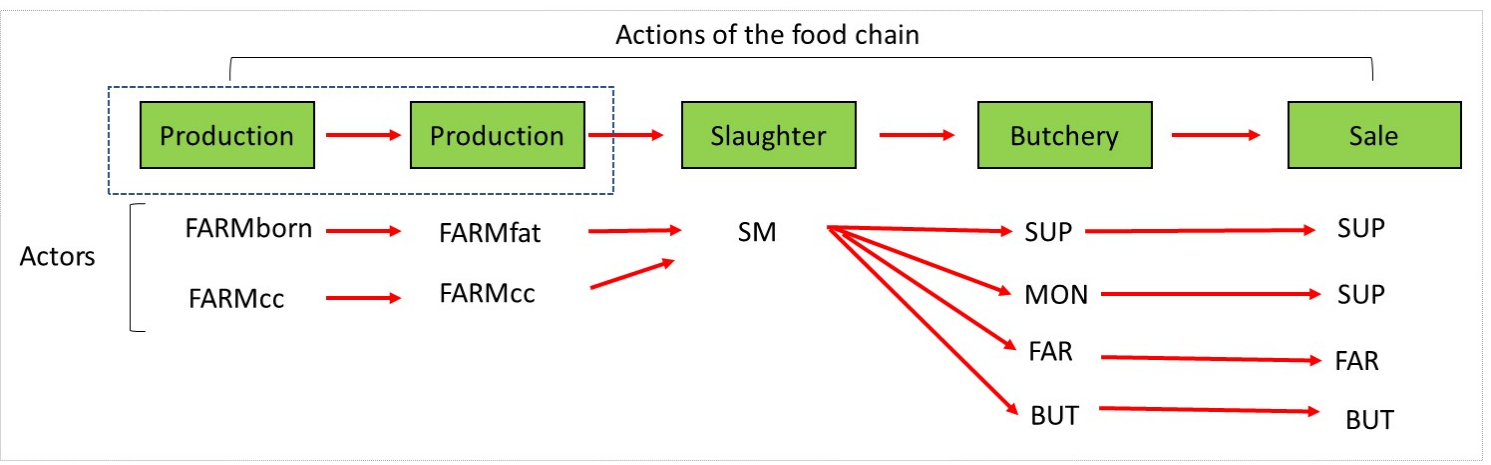

Figure 7. Food value chain detected in 2018. FAR indicates the farms, especially, FARMborn to farms that sells calves; FARMfat to farms that do the fattening of the animals; FARMcc to farms that have the complete cycle of production; SM, the slaughterhouse; SUP, the supermarkets; BUT, the butcheries; and MON refers to a big butchery company. 
The slaughtering is performed by the provincial slaughterhouse, SM, the only public slaughterhouse in the Pisa province. From here, the meat follows different chains according to the different agreements between producers and sellers. When farmers do on-farm direct sale, they also do their own butchery. These farms have all the internal private farm butchery, as well as a sales point. In the case of supermarkets that have their own butchery, they are responsible for the dissection of the meat that they further sell. They just transport the slaughtered animals from SM to their own shop. In the case of supermarket shops that do not have internal butchery, the meat is transported from SM to MON, which is a big butchery company located not far from SM in the Province of Florence. Dissection and packaging into ready-to sell portions is provided by MON, and then from there the meat is sent to the supermarkets' shops. Finally, when the sale is done by butcheries, they take the animals directly from the slaughterhouse. In all the four cases, the final buyers are restaurants and local consumers.

The animal transport from the farm to the SM is paid by the farms, as well as the transport from SM to the farms. On the contrary, the slaughter and the transportation's costs from SM to the supermarkets and butcheries are in charge of the supermarkets. Figure 8 illustrates the food network of CBP label.

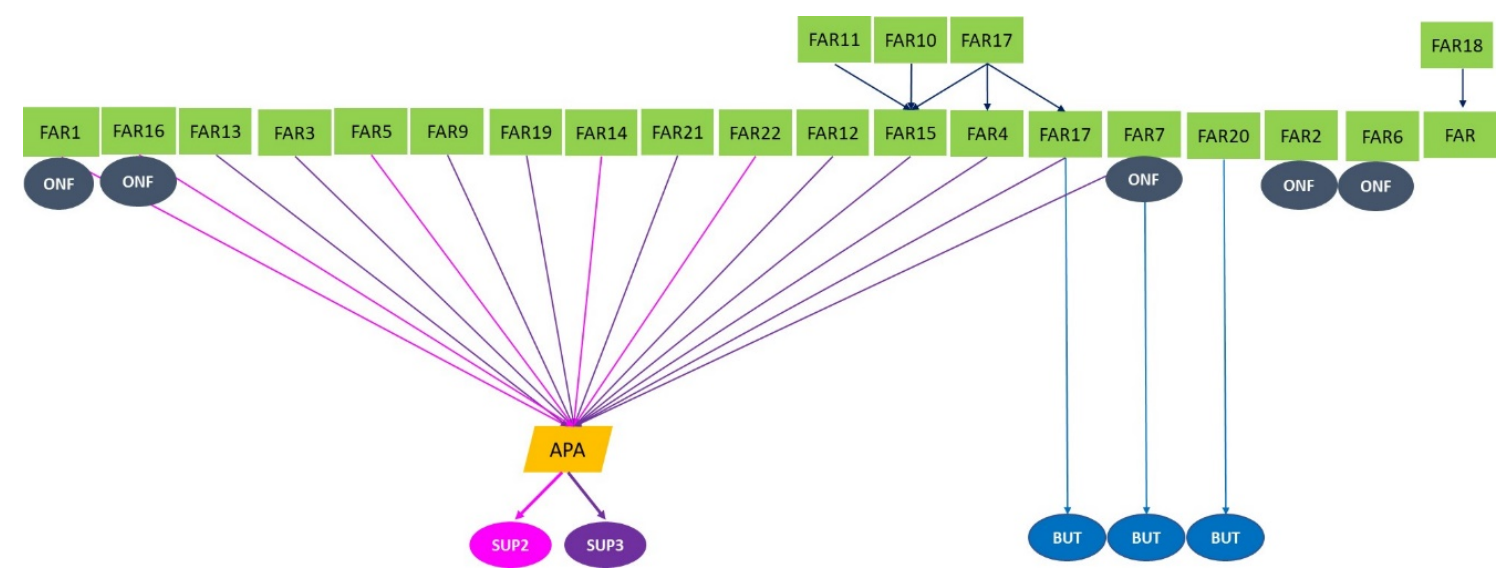

Figure 8. Food network detected in 2018: the sale of the production between farmers (FAR), supermarkets (SUP), butcheries (BUT), and on-farm direct sales (ONF).

The important novelty of the food network detected in 2018 is the interdependency among peri-urban and rural farming systems. In fact, three farms (FAR8, FAR10, and FAR11), all located in peri-urban areas and who cannot do the animal fattening, are selling the animals to farmers (FAR4, FAR15, and FAR17) specialized in the fattening of the animal. The difficulty in the animal fattening is especially connected to the lack of space for feed production in areas under urban pressure.

The increasing number of farmers resulted in a more complex food network. First, five farmers (FAR14, FAR1, FAR16, FAR7, and FAR18) out of twenty-two are doing on-farm direct sale, and only two of them are situated in the peri-urban area (FAR1 and FAR7). While in the beginning the farmers were convinced that the project served to provide a certified product to sustain the on-farm direct sale, nowadays they recognize the opportunity provided by the label to enter in the supply chain of the large-scale distribution (supermarkets). Three farmers doing on-farm direct sale also sell the animals to APA for the supermarkets, confirming a certain integration among the commercialization strategy to supermarkets and through on-farm direct sale (Figure 8).

APA still plays a determinant role in managing the meat provision to the two supermarket chains. In Figure 8 different colors indicate in which of the two different supermarket chains the production is sold. The two supermarkets also sell two different products: SUP2 sells only the meat from Limousine breeding, while SUP3 is specialized on the meat from Mucca Pisana. In this way, there is no competition both in the sale and in provision between them. Another important difference between the two supermarkets lies in the fact that SUP2 sells the meat from Carne Bovina di Pisa project in many shops 
in the Province of Pisa, SUP3 only sells meat from the general label Toscana Toscana in the big shop at Pisa.

According to APA, the production of Mucca Pisana almost covers the demand from SUP3. Respect to the CBP Project, SUP3 in interested only in meat from Mucca Pisana, and clients go there because they want that specific meat. SUP3 has many loyal clients now and a continuous request. Meat from Mucca Pisana needs a much longer maturation time and requires an artisanal processing procedure. For these reasons, SUP3 has invested in special cold-rooms for the Mucca Pisana. Having its own internal butchery, the supermarket buys entire or half-animals.

In the case of SUP2 the meat arrives already processed in the small shops in the Province of Pisa, according to the supermarkets' contracts with MON. On the contrary, the big shops with their own butchery buy entire or half-animals. The percentage of local labelled beef is between $15 \%$ and $20 \%$ on the whole beef sale. The costumers are loyal and have trust in the label; some come just for the CBP beef. These costumers are not only private consumers, but also restaurants that propose the locally produced meat in their menu. In the supermarkets, QR-codes with reference to the farm on the packages guarantee the traceability of the meat, further supporting consumer's trust building. Recently SUP2 has exposed panels with photos and little description of their main local providers in the shops, including the livestock farms of the area. The business strategy of the SUP2 management is focused on traceability, customers' trust building in the producers, local connections, and short and local supply chains. The traceability is an important factor and some shops in the Province of Pisa request especially the meat produced in their municipality. The SUP2 regional managers and the local shops' managers meet every three months to assess the capacity of the local livestock production system to meet the request from local consumers. They have a strong connection with the local farming system, and this is done with the assistance of APA. According to SUP2, the provision is very constant, and a serious lack of supply is unlikely. This is especially because the demand is constant, and the production is well monitored by APA. "The consumer looking for this product is very loyal. Those looking for such a product look for it regardless of whether another type of meat is in promotion. The oscillations of the demand are never so high that they put farmers or the consortium in difficulty."

According to supermarkets, the role of APA is essential: first, they guarantee specific controls of the meat and of animal welfare on the farms by their technical assistance function; and second, they are able to monitor the growth of the animal in each farm, and thus coordinate and guarantee a regular provision to the supermarkets. According to farmers, the role of APA is essential for organizing the supply to the supermarkets. The rules are clear, and supermarkets have adapted to their productive timing. "When they have a need they call me and ask if there is an animal ready, if they do not call, I call them [APA]." Moreover, APA is essential for the price mediation. In general, the price from farmers to supermarkets is higher than the price farmers obtained with other commercial actors. At the same time, the price paid by consumers in supermarkets for CBP meat is one-third higher than for non-labelled national beef, this implies that supermarkets also may have a certain profit from the CBP supply chain. As stated, supermarkets have still continuous requests from consumers. Beyond doing on-farm direct sales, several farmers also use the label to sell directly to local small butcheries. Unfortunately, the number of butcheries that buy CBP meat has decreased significantly, from ten units in 2013 to only three in 2019. The three butcheries are all located in the Province of Pisa and they have direct commercialization with the farmers. In other words, APA does not intervene in the mediation between the farmers and the butcheries. The label created by APA has a positive impact on the economy, and also that of other commercial actors who are not directly touched by APA, such as butcheries and restaurants that buy directly from farmers or in big supermarkets, even though APA manages only the transactions with supermarkets.

APA acts without interest in profit making; this means that they do not gain profit from the transactions between the farmers and the supermarkets. To participate in the project, farmers simply have to be associated to APA as livestock producers and sign the CBP production specification. 
Butcheries, supermarkets, and other commercial actors need to pay an annual fee to the association to be able to use the label for commercialization.

\section{Discussion}

Livestock breeding in the Mediterranean basin has an important function and has shaped typical Mediterranean landscapes for centuries [54,55]. Malek and Verburg (2017) [56] underlined the importance of livestock breeding/production in their classification of Mediterranean land systems, particularly in wetland systems, agro-silvo-pastoral mosaics systems, and bare and open grazed systems. According to Fusco et al. (2019) [57], the land systems including livestock can be found in all the Mediterranean and represent half of the land systems retrieved. Neuman et al. (2009) [58] have simulated the expected changes in livestock numbers by 2030 in Europe in several policy scenarios: all scenarios state similar trends of decline in ruminants, particularly sheep and goats, while beef cattle production is expected to grow, but with a decreasing in the number of farms.

The purpose of this study was to show the contribution of a local food quality label in the resilience of peri-urban livestock farming system and of the food supply chain at territorial level. Following the literature about the farming systems resilience $[5,6,8,9]$, when analyzing the system's resilience, it is important to define the resilience of what, to what, and for what purpose. In this study we analyzed the resilience of peri-urban livestock farms and of the supply chain (Table 3), following the hypothesis that the resilience of the former contributes to the resilience of the second one and vice versa. Each of these two systems faces specific challenges (Table 3). The quality label has made it possible to organize a project, grouping different actors, that with specific actions has tried to propose solutions to these challenges. The real impact in terms of resilience is in the end more complex and articulated for both the two systems (Table 3).

A first element of discussion is that the impact of the project at the moment goes beyond the purpose of the project itself. The impact in fact is not only on the protection of an endangered breed, but on the specific case of peri-urban livestock farming system, as well as on the food chain and on the consumers that have the possibility to have access to local food.

First, even though in the initial phase of the project, the food chain was considered just as a means to be able to create added value for the profitability of livestock farms, this analysis has demonstrated also the positive impact of the project on the resilience of the local supply chains itself. According to our results, the CBP project has served as a pilot project to structure a more enlarged and structured food chain from the farm to the supermarket to sustain the livestock farms in the whole region. In this sense, following the literature on resilience strategy, the creation of the label revealed a "transformative capability" of the system [5], where the creation of the label was a transformative change for the local food system and for the local farming system, not only at local level in the peri-urban area, but also at the provincial and regional level.

The enlargement of the project had several consequences. First, more actors were involved, both on the production and on the sales side. This numerical increase has caused a major complexity of the food network. The farmers still have a certain contracting power with APA regarding the quantity of the meat to devolve to the supermarkets and can decide to sell directly a part of their production to final consumers or other economic actors. The coordination role played by APA is essential in providing regular meat supply, guaranteeing fair prices, and tracing the meat quality. This result is consistent with other analyzes carried out on other LAFS case studies, where the coordination of actors is essential for the success of the food chain project [39]. 
Table 3. Challenges and the resilience strategy and impact of the project CBP.

\begin{tabular}{|c|c|c|c|}
\hline $\begin{array}{l}\text { The Systems: the } \\
\text { "Resilience of What" }\end{array}$ & $\begin{array}{l}\text { Challenges: the } \\
\text { "Resilience to What" }\end{array}$ & $\begin{array}{l}\text { Direct or Indirect } \\
\text { Action of the Project }\end{array}$ & $\begin{array}{l}\text { Impact of the Project in } \\
\text { Line with the Resilience }\end{array}$ \\
\hline \multirow{4}{*}{$\begin{array}{l}\text { On the peri-urban } \\
\text { livestock farming system }\end{array}$} & Urban pressure & $\begin{array}{l}\text { In } 2013 \text {, the project was } \\
\text { especially implemented } \\
\text { by farms localized in the } \\
\text { peri-urban area, so it } \\
\text { seemed to be a source of } \\
\text { resilience adapted to the } \\
\text { peri-urban farmers. }\end{array}$ & $\begin{array}{l}\text { In } 2018 \text { it was observed: } \\
\text { - Integration of peri-urban } \\
\text { and rural livestock } \\
\text { farming systems. } \\
\text { - Livestock farmers have a } \\
\text { label to do direct sale to } \\
\text { consumers and/or } \\
\text { butcheries and restaurants. } \\
\text { - Livestock farms increased } \\
\text { in the peri-urban area. }\end{array}$ \\
\hline & $\begin{array}{l}\text { Decreasing in the } \\
\text { number of livestock } \\
\text { farms. }\end{array}$ & $\begin{array}{l}\text { The purpose of the } \\
\text { project was to sustain the } \\
\text { local breed and the farms } \\
\text { that adopted these } \\
\text { animals in the farms. }\end{array}$ & $\begin{array}{l}\text { - Livestock farms increased } \\
\text { in the peri-urban area. } \\
\text { - The LSU number of } \\
\text { Mucca Pisana is stable. }\end{array}$ \\
\hline & $\begin{array}{l}\text { Product specialization: } \\
\text { tendency of farms to } \\
\text { specialize in crops or in } \\
\text { livestock. }\end{array}$ & $\begin{array}{l}\text { The product specification } \\
\text { states the need for farms } \\
\text { to adopt a crop-livestock } \\
\text { integration. }\end{array}$ & $\begin{array}{l}\text { - No negative constraints } \\
\text { perceived by farmers. }\end{array}$ \\
\hline & $\begin{array}{l}\text { No local food supply } \\
\text { chain present: } \\
\text { - The meat price prior to } \\
\text { the project was very low. } \\
\text { - The small butcheries } \\
\text { were closing; thus, there } \\
\text { was less ability in } \\
\text { processing the } \\
\text { autochthonous breed. }\end{array}$ & $\begin{array}{l}\text { - Marketing and } \\
\text { coordinating action } \\
\text { operated by APA to have } \\
\text { a fair price for both } \\
\text { farmers and } \\
\text { supermarkets as well as } \\
\text { a regular provision. } \\
\text { - Inclusion and } \\
\text { supporting of } \\
\text { commercial actors that } \\
\text { have the know-how to } \\
\text { process the local breed, } \\
\text { especially the } \\
\text { supermarket. }\end{array}$ & $\begin{array}{l}\text { Development of a specific } \\
\text { food supply chain } \\
\text { (transformative). }\end{array}$ \\
\hline \multirow[t]{2}{*}{$\begin{array}{l}\text { On the local food } \\
\text { supply chain }\end{array}$} & $\begin{array}{l}\text { Lack of consumers' trust } \\
\text { in the cattle production } \\
\text { due to food safety crisis. }\end{array}$ & $\begin{array}{l}\text { - Creation of a specific } \\
\text { local label that reassures } \\
\text { consumers and the } \\
\text { commercial actors, } \\
\text { especially supermarkets; } \\
\text { they have trust in the } \\
\text { technical assistance of } \\
\text { APA. } \\
\text { - Promotion operated by } \\
\text { public institutions } \\
\text { especially at the } \\
\text { beginning of the project. }\end{array}$ & $\begin{array}{l}\text { - Increasing demand of } \\
\text { consumers. } \\
\text { - Application of the CBP } \\
\text { project experimentation to } \\
\text { a wider regional context } \\
\text { (transformative). }\end{array}$ \\
\hline & $\begin{array}{l}\text { No market for certain } \\
\text { productions, because: } \\
\text { - Not enough or instable } \\
\text { production. } \\
\text { - Local commercial actors } \\
\text { do not know how to } \\
\text { involve local farmers. }\end{array}$ & $\begin{array}{l}\text { Action of marketing and } \\
\text { coordination of APA. }\end{array}$ & $\begin{array}{l}\text { - Inclusion of other } \\
\text { livestock farms in the } \\
\text { project. } \\
\text { - The production of } \\
\text { Limousine has increased } \\
\text { and that of Mucca Pisana } \\
\text { is stable. } \\
\text { - Diversification of the offer } \\
\text { among the two } \\
\text { supermarkets involved }\end{array}$ \\
\hline
\end{tabular}


Second, the enlargement of the number of actors included in the project has also led to include more and more actors that are not from the peri-urban area. Only in two municipalities of the Province of Pisa, did the supermarkets request to have the meat from cows grown in their municipality. On the other side, the upscaling of the project has led peri-urban farmers with spatial constraints to continue the livestock production, because they can integrate with non-peri-urban farmers. Even though the aim of the project was the general preserving of the livestock production, the project has evolved to further allow the adaptation of the peri-urban farming system. As previous studies have highlighted [41], the constant process of farming adaptation that characterizes the peri-urban farming system can be a source of resilience of farming in these areas. In this sense it has allowed farms with production constraints due to urban pressure to adapt their production cycle. In this sense, the system has revealed a certain "adaptation capability" [5]. In order to be able to include farmers with specific conditions of production, the system has adapted their participation in the project to also include farmers who do only the fattening of the animals. This was essential for both the resilience of the peri-urban farming system and for the resilience of local food supply.

This result is interesting for the LAFS literature, since it provides new insights about how farmers with different production strategies can operate in the framework of the same label and coordinate their actions. In other words, following the LAFS approach, the project has made it possible to further territorialize the agricultural production according to the specific production conditions of farmers [36,59]. While several scholars $[43,44]$ have observed the risk of LAFS literature to simplify the inherent complexity of place, assigning the same production capacity to a farming system operating in different places, this study sustains a possible way to integrate different places of production, such as peri-urban and rural areas. We show how different farms located in peculiar places can anyway contribute to the development of the same label. This evidence can help us to understand how to better territorialize the food production in the framework of quality schemes and regulations.

Our results suggest that peri-urban farms tend to prefer to sell calves. Such territorial specialization between farms selling only calves and farms fattening the animals can explain the increase in bovine LSUs in the area, further contributing to the resilience of the livestock systems. In addition, it can offer opportunities to exploit the production of open field crops (corn, grain, and fodder) both in terms of farms' income and in terms of soil protection, for example, by the integration of manure in farms with arable crops-oriented farms. The development of a fattening activity is therefore an opportunity for arable-oriented farms in the peri-urban area of Pisa to manage natural resources in a more sustainable way. This is consistent with the literature on livestock-crops farming system integration [8,21].

In all this, APA plays a determinant role in managing the food network among farmers and supermarkets, with positive externalities for the sustainable development of many different economic actors. The role of these "intermediate" or "boundary" actors is relevant also in peri-urban areas as highlighted by Kovach and Kristof [60].

The results on quantitative data on the cattle dynamics reveal that the label has sustained the resilience of a specific livestock production in the area, as suggested by the literature [25], especially, according to results, when there is a difference between the breeds covered by the quality labels. While the values on the breed Chianina are decreasing, the numbers for the breeds, Limousine, are increasing and that for the Mucca Pisana are stable in the peri-urban area. The Chianina production is covered by a Protected Geographical Indication (PGI) certification, the Vitellone Bianco dell'Appennino Centrale (White Breed Baby Beef from Central Appennine). It is thus recognized as a typical and traditional production of the Central Italy and its place of production covers several Italian regions [61]. In other words, even if it is marketed as a typical and local production, the effective local basin of production is at supraregional scale. On the contrary, the CBP denotes very specific local production, and the basin of production is confined within the limits of the province. Moreover, the Vitellone Bianco dell'Appennino Centrale PGI based on Chianina breed is highly recognized by consumers in regional (Central Italy) and national levels, while CBP has a very local consumer basin, since it is sold only in the Province of Pisa. Our results suggest that it is not simply the quality scheme of a local food that 
may sustain the production, or the reference to a specific territory, but also the capacity of the label to be connected to its territory of production and consumption.

\section{Conclusions}

To conclude, livestock productions are essential for the sustainable development of agricultural areas. This study confirms the importance of coordinated actions between different stakeholders in ensuring the resilience of livestock farms even in constrained places such as peri-urban areas. In this study, the focus was on the resilience of a farming system in areas under urban pressure. Further studies may address this issue in other land systems in the Mediterranean area, as well as the impact of food quality labels on livestock dynamics. Specific projects of quality valorization may thus positively valorize the territorial anchorage of farming systems taking into account the specific conditions of production.

This study provides interesting insights for other case studies to develop similar strategies of resilience. Especially, this study can put light on how different farming systems with different territorial conditions of production can integrate their production strategies and participate in the same quality scheme and in the same local food supply chain. The study is also important to understand the importance for the participation of different actors in the same supply chain, such as small economic activities like small butcheries and supermarkets. Finally, the study provides important insights for future research, since it provides a framework of analysis for similar situations, and also follows the purpose of LAFS approach, which aims is to analyze the local development of rural areas.

Author Contributions: Conceptualization, R.F., E.M. and S.L.; methodology, R.F. and E.M.; software, T.S.; validation, R.F., S.G.-S., T.S., S.L. and E.M.; formal analysis, R.F. and E.M.; investigation, R.F., S.G.-S. and T.S.; data curation, R.F. and T.S.; writing-original draft preparation, R.F. and E.M.; writing-review and editing, R.F., S.G.-S., T.S., S.L. and E.M.; supervision, E.M.; project administration, R.F. and E.M.; and funding acquisition, T.S. and S.L. All authors have read and agreed to the published version of the manuscript.

Funding: We acknowledge the contribution of the DIVERCROP and DAUME projects. DIVERCROP is funded through the ARIMNet2 2016 Call by the following funding agencies: ANR (France), IRESA (Tunisia), INIA (Spain), FCT (Portugal), ATRSNV (Algeria), MIPAAF (Italy), and MCST (Malta). ARIMNet2 (ERA-NET) received funding from the European Union's Seventh Framework Programme for research, technological development, and demonstration under grant agreement $\mathrm{n}^{\circ}$ 618127. DAUME was funded by ANR funding via the project ANR-2010-STRA-007-01.

Acknowledgments: We warmly thank all the actors that have participated in this study since 2013, and particularly Riccardo Belluomini from the APA staff.

Conflicts of Interest: The authors declare no conflict of interest. The funders had no role in the design of the study; in the collection, analyzes, or interpretation of data; in the writing of the manuscript; or in the decision to publish the results.

\section{References}

1. Darnhofer, I. Strategies of Family Farms to Strengthen Their Resilience. Environ. Policy Gov. 2010, 20, $212-222$. [CrossRef]

2. López-ridaura, S.; Van Keulen, H.; Van Ittersum, M.K.; Leffelaar, P.A. Multiscale Methodological Framework to Derive Criteria and Indicators for Sustainability Evaluation of Peasant Natural Resource Management Systems. Environ. Dev. Sustain. 2005, 7, 51-69. [CrossRef]

3. Tendall, D.M.; Joerin, J.; Kopainsky, B.; Edwards, P.; Shreck, A.; Le, Q.B.; Kruetli, P.; Grant, M.; Six, J. Food System Resilience: Defining the Concept. Glob. Food Secur. 2015, 6, 17-23. [CrossRef]

4. Darnhofer, I. Resilience and Why It Matters for Farm Management. Eur. Rev. Agric. Econ. 2014, 41, 461-484. [CrossRef]

5. Walker, B.; Holling, C.S.; Carpenter, S.R.; Kinzig, A.P. Resilience, Adaptability and Transformability in Social-Ecological Systems. Ecol. Soc. 2004, 9, 5. [CrossRef]

6. Folke, C.; Carpenter, S.R.; Walker, B.; Scheffer, M.; Chapin, T.; Rockström, J. Resilience Thinking: Integrating Resilience, Adaptability and Transformability. Ecol. Soc. 2010, 15, 20. [CrossRef] 
7. Ashkenazy, A.; Calvão Chebach, T.; Knickel, K.; Peter, S.; Horowitz, B.; Offenbach, R. Operationalising Resilience in Farms and Rural Regions-Findings from Fourteen Case Studies. J. Rural Stud. 2018, 59, 211-221. [CrossRef]

8. Carpenter, S.; Walker, B.; Anderies, J.M.; Abel, N. From Metaphor to Measurement: Resilience of What to What? Ecosystems 2001, 4, 765-781. [CrossRef]

9. Meuwissen, M.P.M.; Feindt, P.H.; Spiegel, A.; Termeer, C.J.A.M.; Mathijs, E.; De Mey, Y.; Finger, R.; Balmann, A.; Wauters, E.; Urquhart, J.; et al. A Framework to Assess the Resilience of Farming Systems. Agric. Syst. 2019, 176, 102656. [CrossRef]

10. European Commission. Economic Impact of the Abolition of the Milk Quota Regime-Regional Analysis of the Milk Production in the EU; JRC-IPTS: Seville, Spain, 2009; p. 10.

11. OECD. Meat Consumption (Indicator). Available online: https://www.eea.europa.eu/data-and-maps/daviz/ per-capita-eu-27-consumption-1 (accessed on 25 June 2020).

12. Eurostat. Agricultural Production—Livestock and Meat; Eurostat: Brussels, Belgium, 2020.

13. Martin, G.; Moraine, M.; Ryschawy, J.; Magne, M.-A.; Asai, M.; Sarthou, J.-P.; Duru, M.; Therond, O. Crop-Livestock Integration beyond the Farm Level: A Review. Agron. Sustain. Dev. 2016, 36, 53. [CrossRef]

14. Moraine, M.; Duru, M.; Nicholas, P.; Leterme, P.; Therond, O. Farming System Design for Innovative Crop-Livestock Integration in Europe. Animal 2014, 8, 1204-1217. [CrossRef]

15. EEA. Integration of Environment into EU Agriculture Policy: The IRENA Indicator-Based Assessment Report; Office for Official Publications of the European Communities: Luxembourg, 2006.

16. Paül, V.; McKenzie, F.H. Peri-Urban Farmland Conservation and Development of Alternative Food Networks: Insights from a Case-Study Area in Metropolitan Barcelona (Catalonia, Spain). Land Use Policy 2013, 30, 94-105. [CrossRef]

17. Filippini, R.; Lardon, S.; Bonari, E.; Marraccini, E. Unraveling the Contribution of Periurban Farming Systems to Urban Food Security in Developed Countries. Agron. Sustain. Dev. 2018, 38, 21. [CrossRef]

18. Filippini, R. Food Production Potential of Periurban Agriculture: Contribution of Periurban Farms to Local Food Systems; Scuola Superiore Sant'Anna: Pisa, Italy; AgroParisTech: Paris, France, 2015.

19. Bloom, J.D.; Hinrichs, C.C. Moving Local Food through Conventional Food System Infrastructure: Value Chain Framework Comparisons and Insights. Renew. Agric. Food Syst. 2011, 26, 13-23. [CrossRef]

20. Busck, A.G.; Kristensen, S.B.P. From Agriculture to Nature-A Study of Drivers of Land Use Change in a Peri-Urban Landscape. Geogr. Tidsskr.-Dan. J. Geogr. 2014, 114, 41-58. [CrossRef]

21. Graef, F.; Schneider, I.; Fasse, A.; Germer, J.U.; Gevorgyan, E.; Haule, F.; Hoffmann, H.; Kahimba, F.C.; Kashaga, L.; Kissoly, L.; et al. Assessment of Upgrading Strategies to Improve Regional Food Systems in Tanzania: Food Processing, Waste Management and Bioenergy, and Income Generation. Outlook Agric. 2015, 44, 179-186. [CrossRef]

22. Diogo, R.V.C.; Schlecht, E.; Buerkert, A.; Rufino, M.C.; Van Wijk, M.T. Increasing Nutrient Use Efficiency through Improved Feeding and Manure Management in Urban and Peri-Urban Livestock Units of a West African City: A Scenario Analysis. Agric. Syst. 2013, 114, 64-72. [CrossRef]

23. Tedesco, C.; Petit, C.; Billen, G.; Garnier, J.; Personne, E. Potential for Recoupling Production and Consumption in Peri-Urban Territories: The Case-Study of the Saclay Plateau near Paris, France. Food Policy 2017, 69, $35-45$. [CrossRef]

24. Abu Hatab, A.; Cavinato, M.E.R.; Lagerkvist, C.J. Urbanization, Livestock Systems and Food Security in Developing Countries: A Systematic Review of the Literature. Food Secur. 2019, 11, 279-299. [CrossRef]

25. Filippini, R.; Marraccini, E.; Lardon, S.; Bonari, E. Assessing Food Production Capacity of Farms in Periurban Areas. Ital. J. Agron. 2014, 9, 63-70. [CrossRef]

26. Duvernoy, I.; Zambon, I.; Sateriano, A.; Salvati, L. Pictures from the Other Side of the Fringe: Urban Growth and Peri-Urban Agriculture in a Post-Industrial City (Toulouse, France). J. Rural Stud. 2018, 57, 25-35. [CrossRef]

27. Gullino, P.; Battisti, L.; Larcher, F. Linking Multifunctionality and Sustainability for Valuing Peri-Urban Farming: A Case Study in the Turin Metropolitan Area (Italy). Sustainability 2018, 10, 1625. [CrossRef]

28. Scheromm, P.; Soulard, C.T. The Landscapes of Professional Farms in Mid-Sized Cities, France: Professionnal Farming in Mid-Sized Cities. Geogr. Res. 2018, 56, 154-166. [CrossRef] 
29. Busck, A.G.; Kristensen, S.P.; Præstholm, S.; Reenberg, A.; Primdahl, J. Land System Changes in the Context of Urbanisation: Examples from the Peri-Urban Area of Greater Copenhagen. Geogr. Tidsskr. 2006, 106, 21-34. [CrossRef]

30. Zasada, I. Multifunctional Peri-Urban Agriculture-A Review of Societal Demands and the Provision of Goods and Services by Farming. Land Use Policy 2011, 28, 639-648. [CrossRef]

31. Zasada, I.; Berges, R.; Hilgendorf, J.; Piorr, A. Horsekeeping and the Peri-Urban Development in the Berlin Metropolitan Region. J. Land Use Sci. 2013, 8, 199-214. [CrossRef]

32. Bonaudo, T.; Bendahan, A.B.; Sabatier, R.; Ryschawy, J.; Bellon, S.; Leger, F.; Magda, D.; Tichit, M. Agroecological Principles for the Redesign of Integrated Crop-Livestock Systems. Eur. J. Agron. 2014, 57, 43-51. [CrossRef]

33. Duru, M.; Therond, O. Livestock System Sustainability and Resilience in Intensive Production Zones: Which Form of Ecological Modernization? Reg. Environ. Chang. 2015, 15, 1651-1665. [CrossRef]

34. Ansaloni, F. Trasformazione Aziendale e Filiera Corta della Carne Bovina. Available online: http:// agriregionieuropa.univpm.it/dettart.php?id_articolo=485 (accessed on 17 September 2013).

35. Tregear, A.; Arfini, F.; Belletti, G.; Marescotti, A. Regional Foods and Rural Development: The Role of Product Qualification. J. Rural Stud. 2007, 23, 12-22. [CrossRef]

36. Arfini, F.; Cozzi, E.; Mancini, M.C.; Ferrer-Perez, H.; Gil, J.M. Are Geographical Indication Products Fostering Public Goods? Some Evidence from Europe. Sustainability 2019, 11, 272. [CrossRef]

37. Fournier, S.; Muchnik, J. Le Système Agroalimentaire Localisé Pour Analyser Le Territoire. TRAV Innov. 2011, 181, 27-30.

38. Belletti, G.; Casabianca, F.; Marescotti, A. Local Food Quality and Local Resources. In Local Agri-Food Systems in a Global World: Market, Social and Environmental Challenges; Arfini, F., Mancini, M.C., Donati, M., Eds.; Cambridge Scholars Publishing: Newcastle upon Tyne, UK, 2012; pp. 71-97.

39. Giacomini, C.; Mancini, M.C. Organisation as a Key Factor in Localised Agri-Food Systems (LAFS). Bio-Based Appl. Econ. 2015, 4, 17-32.

40. Sanz-Cañada, J.; Muchnik, J. Geographies of Origin and Proximity: Approaches to Local Agro-Food Systems. Cult. Hist. Digit. J. 2016, 5, 1-19. [CrossRef]

41. Tolron, J.-J. L'agriculture Périurbaine: Paradigme et Paradoxes d'une Péri-Agriculture. Illustration En Région Méditerranéenne. Ingénieries-EAT 2001, 28, 65-74.

42. Heimlich, R.; Anderson, W. Development at the Urban. Fringe and Beyond: Impacts on Agriculture and Rural; Agricultural Economic Report No. (AER-803); Economic Research Service, U.S. Department of Agriculture: Washington, DC, USA, 2001.

43. Feagan, R. The Place of Food: Mapping out the "local" in Local Food Systems. Prog. Hum. Geogr. 2007, 31, 23-42. [CrossRef]

44. Sonnino, R. The Power of Place: Embeddedness and Local Food Systems in Italy and the UK. Anthropol. Food 2007. [CrossRef]

45. Marraccini, E.; Debolini, M.; Moulery, M.; Abrantes, P.; Bouchier, A.; Chéry, J.-P.; Sanz Sanz, E.; Sabbatini, T.; Napoleone, C. Common Features and Different Trajectories of Land Cover Changes in Six Western Mediterranean Urban Regions. Appl. Geogr. 2015, 62, 347-356. [CrossRef]

46. Ruiz-Martinez, I.; Gennai-Schott, S.; Sabbatini, T.; Bonari, E.; Marraccini, E. Farming Systems Dynamics at the Urban Region Level: The Case of The Area Pisana. In La Ricerca Agronomica verso il 2030: Gli Obiettivi Globali di Sviluppo Sostenibile; Università di Sassari: Sassari, Italy, 2016.

47. Associazione Italiana Allevatori. Registro Anagrafico Delle Razze Bovine Autoctone a Limitata Diffusione; AIA: Rome, Italy, 2013.

48. Filippini, R.; Lardon, S.; Sabbattini, T.; Marraccini, E. Quality Labels as Drivers of Periurban Livestock Farming Resilience. In Proceedings of the 13th European International Farming Systems Association (IFSA) Symposium, Farming Systems: Facing Uncertainties and Enhancing Opportunities, Chania, Greece, 1-5 July 2018; pp. 1-13.

49. Toscana Allevatori. Carne Bovina Toscana/Toscana; Associazione Regionale Allevatori della Toscana: Florence, Italy, 2017; Available online: http://www.toscanallevatori.it/wp-content/uploads/2017/06/Bovini_Toscana_ Toscana.pdf (accessed on 8 May 2020).

50. Associazione Regionale Allevatori della Toscana. Disciplinare del marchio Carne Bovina Toscana/Toscana; Associazione Regionale Allevatori della Toscana: Florence, Italy, 2018. 
51. Istituto Zooprofilattico Sperimentale. Available online: http://statistiche.izs.it/portal/page?_pageid=73, 12918\&_dad=portal\&_schema=PORTAL\&op=elenco_rep\&p_report=plet_rep_bov\&p_titolo=Bovini $\%$ 20e\%20Bufalini (accessed on 15 May 2020).

52. Lockie, S.; Kitto, S. Beyond the Farm Gate: Production-Consumption Networks and Agri-Food Research. Sociol. Rural. 2000, 40, 3-19. [CrossRef]

53. Raynolds, L.T. The Globalization of Organic Agro-Food Networks. World Dev. 2004, 32, 725-743. [CrossRef]

54. Blondel, J. The 'Design' of Mediterranean Landscapes: A Millennial Story of Humans and Ecological Systems during the Historic Period. Hum. Ecol. 2006, 34, 713-729. [CrossRef]

55. Pinto-Correia, T.; Ribeiro, N.; Sá-Sousa, P. Introducing the Montado, the Cork and Holm Oak Agroforestry System of Southern Portugal. Agrofor. Syst. 2011, 82, 99-104. [CrossRef]

56. Malek, Ž.; Verburg, P. Mediterranean Land Systems: Representing Diversity and Intensity of Complex Land Systems in a Dynamic Region. Landsc. Urban Plan. 2017, 165, 102-116. [CrossRef]

57. Fusco, J.; Marraccini, E.; Debolini, M. Intensification, Periurbanization and Specialization of Agriculture as Significant Short-Term Land System Dynamics in the Mediterranean Basin. In Proceedings of the Colloque SAGEO; Bimonte, S., Lardon, S., Eds.; SAGEO: Clermont-Ferrand, France, 2019.

58. Neumann, K.; Elbersen, B.S.; Verburg, P.H.; Staritsky, I.; Pérez-Soba, M.; De Vries, W.; Rienks, W.A. Modelling the Spatial Distribution of Livestock in Europe. Landsc. Ecol. 2009, 24, 1207-1222. [CrossRef]

59. Fournier, S.; Muchnik, J. L'approche "Systèmes Agroalimentaires Localisés" (SYAL), Un Outil D'intervention Pour Le Développement Territorial? ISDA: Montpellier, France, 2010.

60. Kovach, I.; Kristof, L. The Role of Intermediate Actors in Transmitting Rural Goods and Services in Rural Areas under Urban Pressure. J. Environ. Policy Plan. 2009, 11, 45-60. [CrossRef]

61. European Commission. Vitellone Bianco Dell'Appennino Centrale-Product Specification; European Commission: Brussels, Belgium, 2018.

(C) 2020 by the authors. Licensee MDPI, Basel, Switzerland. This article is an open access article distributed under the terms and conditions of the Creative Commons Attribution (CC BY) license (http://creativecommons.org/licenses/by/4.0/). 